Erwin Hepperle, Robert W. Dixon-Gough, Thomas Kalbro, Reinfried Mansberger, Kim Meyer-Cech (eds.)

\title{
Core-Themes of Land Use Politics: Sustainability and Balance of Interests
}

\section{Kernthemen der Bodenpolitik: Nachhaltige Entwicklung und Interessenausgleich}

FACULTÉ EUROPÉENNE DES SCIENCES DU FONCIER EUROPÄISCHE FAKULTÄT FÜR BODENORDNUNG

EUROPEAN FACULTY OF LAND USE AND DEVELOPMENT 
tha an der ETHZurich

lag A an der ETHzurich ovaf Hochsolnulverlag

erlag AG an der ETHzurich (o val Hochschulverlag AG an der ETH Zurich

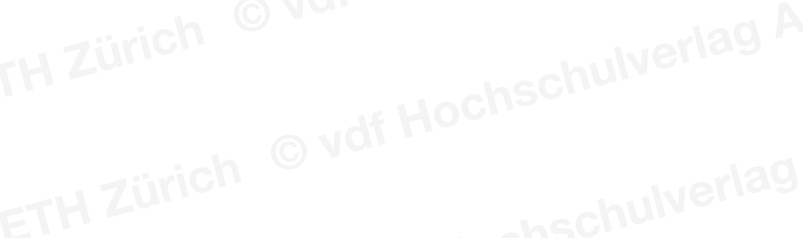

Charlag Actan der ETHzurich ovaf Hochsory

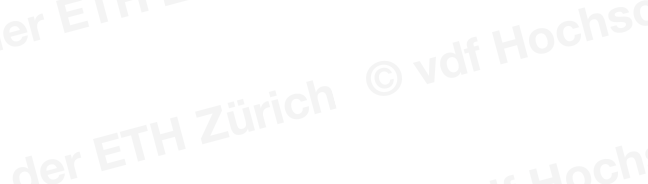

ETHZzurich Ovdr Hochs

-

- chulvertag $A G$ an der ETH zurich O vdf

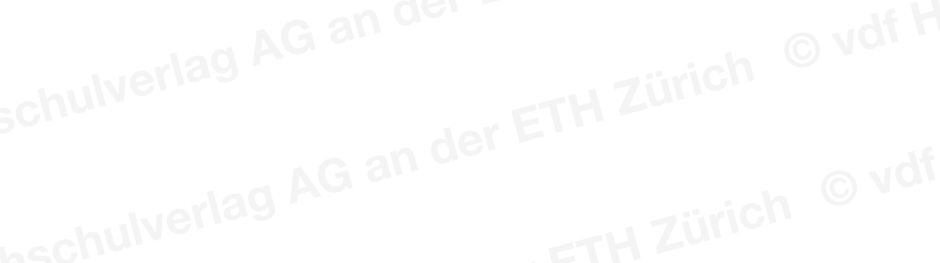

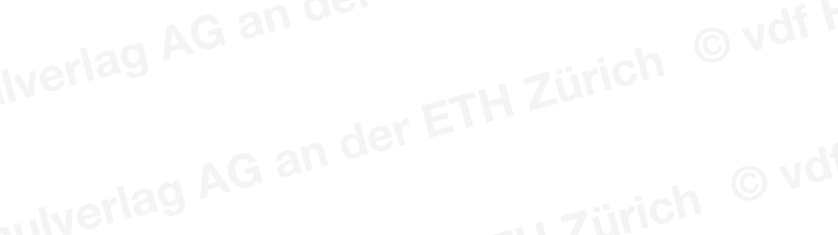

A an der ETHzurich

arag Aan der ETHZzurich 
Core-Themes of Land Use Politics: Sustainability and Balance of Interests

Kernthemen der Bodenpolitik:

Nachhaltige Entwicklung und Interessenausgleich 
ha an der ETHZurich

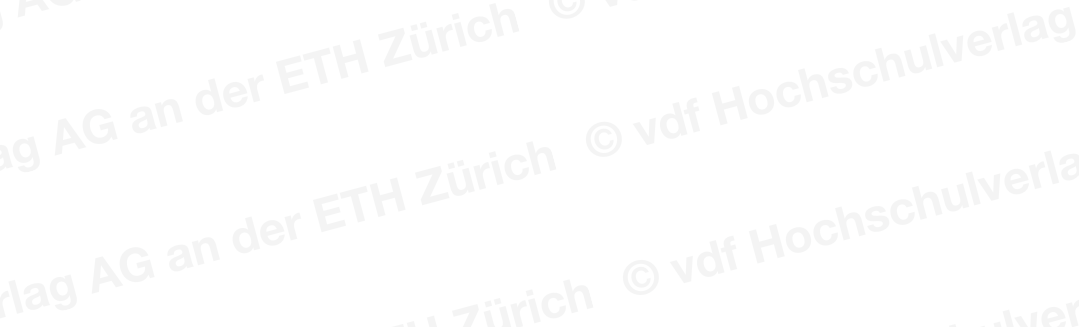

erlag AG an der ETHzurich ovaf Hochschulverlag AG an der ETH Zurich

a zurich ovdithochschulverlag

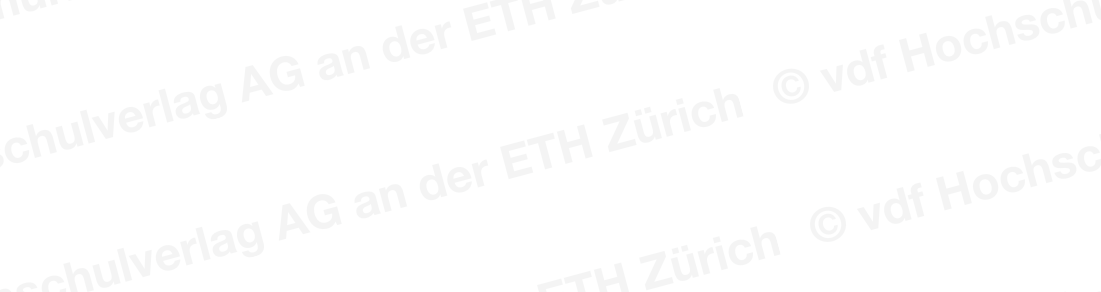

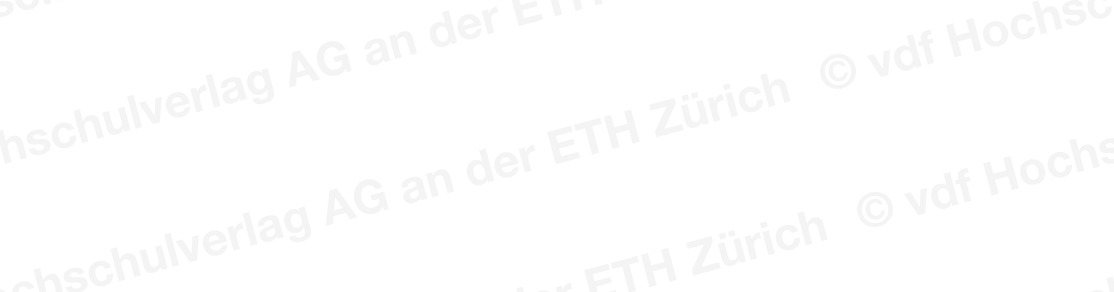

der ETHzurich ovdritochschulverlag $A G$ an dert

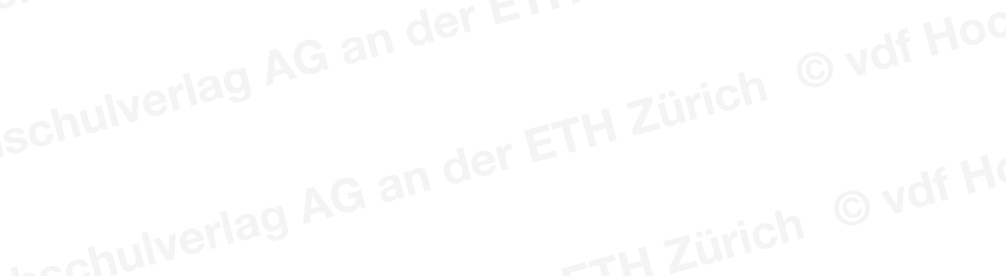

RG an der ETH Zurich ovdf

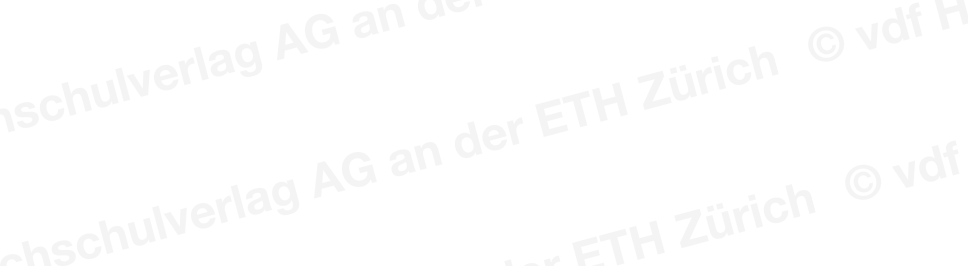

Gan der ETHzurich O v

AG an der ETHzurich O 
Erwin Hepperle, Robert W. Dixon-Gough, Thomas Kalbro, Reinfried Mansberger, Kim Meyer-Cech (eds.)

\section{Core-Themes of Land Use Politics: Sustainability and Balance of Interests}

\section{Kernthemen der Bodenpolitik: Nachhaltige Entwicklung und Interessenausgleich}

FACULTÉ EUROPÉENNE DES SCIENCES DU FONCIER

EUROPÄISCHE FAKULTÄT FÜR BODENORDNUNG

EUROPEAN FACULTY OF LAND USE AND DEVELOPMENT

V/d If vdf Hochschulverlag AG an der ETH Zürich 


\section{This work is licensed under a creative commons license 通

\section{Bibliografische Information der Deutschen Nationalbibliothek}

Die Deutsche Nationalbibliothek verzeichnet diese Publikation in der Deutschen Nationalbibliografie; detaillierte bibliografische Daten sind im Internet über http://dnb.d-nb.de abrufbar.

ISBN 978-3-7281-3338-o (Printausgabe) 중

Download open access:

ISBN 978-3-7281-3375-5 / DOI 10.3218/3375-5

www.vdf.ethz.ch एत्र

(c) 2011, vdf Hochschulverlag AG an der ETH Zürich

Umschlaggestaltung: Isabel Thalmann, buchundgrafik.ch 


\section{Preface}

In 2009 the European Faculty of Land Use and Development has launched a new book series published by vdf Hochschulverlag AG Zürich. The present peer reviewed collection of papers is the second volume in this series. Most of the contributions now published go back on presentations that were held during the 36th Symposium and the 37th Symposium of the faculty. Their general theme was "Core Problems of Sustainable Land Management" and "Balance between the public and private interests", respectively. Special thanks go to the Swiss Federal Office for Spatial Development for its financial support of the Symposium in Zurich.

As a peculiarity of the Symposia, the faculty languages include English and German and consequently papers in this volume are also presented in both languages. Contributions come from different disciplines and cover a range of subjects that one can divide roughly into three parts. The first group of papers deals in a general way with problems of sustainable land use, its regulation and requirements for priority setting. The second group puts a special focus on planning processes in different states. The third is treating special issues of high practical relevance such as natural hazards or rural development. However, the topics are interrelated across the scope of subject areas. The book finishes with two articles giving an overview and debating on the current situation of land market in Russia. The editors express their gratitude to the authors for their special effort converting their presentations into scientific papers.

The meetings showed that the regularly cross-disciplinary scientific exchange, as it is practiced by our association, is becoming more and more important since although the finite nature of land and soil ecosystem services are recognized throughout Europe in practice, they are not sufficiently concerned. It is the idea of the new book series not only to disseminate the information on recent and ongoing developments among experts but also to give impulse and raw material for scientists working in other areas.

Erwin Hepperle, Swiss Federal Institute of Technology (ETH) Zürich, Switzerland President of the European Faculty of Land Use and Development 
Inhalt

Ruşen Keleş

How to Reconcile Private Interests with the Public Interest?

Hans Lenk

Zur Umweltverträglichkeit, Nachhaltigkeit und Humanzuträglichkeit

Daniel Wachter, Doris Angst

Boden und Nachhaltige Entwicklung.

Fabian Cortesi, Erwin Hepperle

Impacts of Megatrends on Soils

Meltem Yilmaz

Protection of Natural and Cultural Heritage in the Light of Sustainable Development .... 71

Robert Dixon-Gough, Józef Hernik, James Dixon-Gough

Sustainability and the Cultural Landscape

Maruška Šubic Kovač

Land Use and Development Between Public and Private Interests - Slovenian

Experiences

Audrius Aleknavicius, Jelena Liaskovskaja

Priorities of the Public Interest While Executing the Land Reform During 1991-2008

in Lithuania

Peter Ekbäck, Thomas Kalbro

Expropriation and Prejudicial Effects of Time-Consuming Planning Processes

Alexandra Weitkamp

Die Unternehmensflurbereinigung in der Praxis

Laila Kule, August E. Røsnes

Balancing Developers' Interests in Planning Control.

Hans Mattsson

Purchase and Subdivision Processes in the Nordic Countries.

Jenny Paulsson

Private and Common Responsibilities for the Management of Condominiums

Theo Kötter

Raumplanung und Risikomanagement.

Walter Seher

Integrated Flood Management in Austria - The Contribution of Spatial Planning

Erwin Hepperle

Grundrechtsschutz und Eigenverantwortung beim Schutz vor Naturgefahren 
Erich Weiß

Bodenordnungsmaßnahmen nach dem Flurbereinigungsgesetz zur

Gewässergestaltung

László Dorgai, Judit Nyíri, Andrea Pödör

Change in Land Use in the River Tisza Valley.....

Eidar Lindgren

Shore Protection in Sweden - Efficiency or Waste of Space?

Reinfried Mansberger, Walter Seher, Katalin Gombas, János Katona, Judit Nyiri, Andrea Pödör

Geoinformation in der österreichischen Ländlichen Neuordnung

Winrich Voß

Nachhaltiges Land- und Immobilienmanagement

Markus Schaffert

GIS-basiertes Leerstandsmanagement für ländliche Wohngebäude

Silja Lockemann

Leerstandsproblematik unter Wertermittlungsaspekten

Nikolay Volovitch, Semyon Fomin, Marina Fedotova

Understanding the Problem of Investment Demand for Land in Russia

Nikolay Volovitch, Semyon Fomin

Can Russia Build a Non-Profit Capitalism? 


\section{Shore Protection in Sweden \\ - Efficiency or Waste of Space?}

\section{Introduction}

Many countries have special rules on waterside building. Restrictions, e.g. on housing development near water, can be justified in terms of accident risks and environmental impact, or may be founded on the political balancing of different interests. Land use and building in Sweden are mainly governed by the Planning and Building Act ${ }^{1}$, the provisions of which can also be applied to shoreline zones, e.g. in order to steer building development clear of places prone to landslips or flooding. The shore protection provisions of the Environmental Code 2 apply conjointly with those of the Planning and Building Act. Shore protection is a general prohibition of measures in a shoreline area which would impede the general public from getting near the water or would significantly impact on the natural environment.

Shore protection in Sweden is based on the ability of the general public to move freely on another person's land, so long as no damage is caused to the property, no encroachment is made on a curtilege and the landowner's activity is not impeded. This Right of Public Access is not at all closely defined by statute but is best described as customary law of ancient standing. The strong position of the Right of Public Access is reaffirmed by Swedish constitutional law as follows: "Everyone shall have access to the natural environment through the Right of Public Access...".3 The Right of Public Access enables each individual to bathe and engage in outdoor activity in undeveloped shoreline areas, no matter who owns them. Shore protection applies to all shoreline areas as a safeguard for unimpeded public access.

As from 1st July 2009, shoreline building development is permissible in certain parts of Sweden if the development/project furthers rural development. The new provisions do not apply, however, to single buildings in remote locations. The provisions on shore protection do not in this latter instance take into account the fact that in many sparsely populated regions undeveloped shores are widely available, at the same time as the level of building activity there is low. Furthermore, no distinction is made between nearby, muchvisited shores and remote, rarely visited ones. In other words, all shores which can be used by the general public by virtue of the Right of Public Access are deemed equally deserving of protection, and the ban on construction of single, remotely situated buildings and build-

\footnotetext{
Division of Real Estate Planning and Land Law, Royal Institute of Technology (KTH), Stockholm, Sweden.

1 SFS 1987:10.

2 SFS 1998:808.

3 SFS 1974:152, Chap. 2, Section 18 (3).
} 
ings which cannot be shown to favour rural development applies equally in all places. $4 \mathrm{My}$ question is whether such a general proscription of building is reasonable in a country which is unusually well-endowed with shores and where conditions differ appreciably from one region to another.

\section{The Shore Protection Provisions of the Environmental Code}

The provisions on shore protection are contained in Chap. 7, Sections 13-18 and 25-26 of the Environmental Code. The purpose of shore protection is defined as being: to ensure long-term public access to outdoor recreation facilities and to maintain good living conditions for plant and animal species on land and in water.

Erection of new buildings is prohibited within a shore protection zone. 5 So too is the alteration of a building or its use if the general public are thereby prevented or impeded from entering an area where they would otherwise have been entitled to move freely. This latter prohibition refers primarily to the conversion of previously non-housing buildings a boathouse or a barn, for example - for housing use, because this reduces the ability of the general public to invoke the Right of Public Access when frequenting the vicinity of the building. In addition to buildings, it is also prohibited to construct other facilities which impede or prevent the general public from entering an area where they would otherwise be entitled to move freely. "Privatisation" measures of this kind include, for example, fencing, arbours, garden plots and tennis courts.

It is also prohibited within a shore protection zone to take measures which significantly change the living conditions for flora and fauna, e.g. excavation, dredging or muckspreading. Part of the purpose here is to protect areas of shallow water where favourable light and nutrient conditions encourage the reproduction of many fish species.

Shore protection as a rule applies along all shorelines, by the sea, beside lakes, along watercourses and round islands. Normally it covers the land and water area 100 metres from the shoreline, but it can be enlarged to, at most, 300 metres inland and off shore. Shore protection can be cancelled in an area where it manifestly has no bearing on the purposes of such protection. This normally happens in places where building development is permitted in a detailed development plan drawn up under the Planning and Building Act or earlier building legislation. ${ }^{6}$

4 Prop. 1997/98:45 pp. 88-89, 98.

5 This prohibition does not include buildings, facilities and measures necessary for the conduct of farming, fishing, forestry or reindeer husbandry.

6 The provisions on shore protection apply parallel to planning and building legislation. In practice a coordination has been effected, so that plans which confer building rights under the Planning and Building Act will not include a building prohibition under the shore protection provisions. 
The prohibitions in force can be waived only where there are "special reasons" for so doing. 7 The statutory text indicates possible "special reasons". ${ }^{8}$ Exemptions can be granted principally in the following situations.

a) The intended building site is not accessible to the general public, e.g. because it has been used previously for housing purposes.

b) The place is separated from the shore by an existing physical obstacle (a railway or major road, buildings etc.) and the intended building measure is of no consequence for use of the shore.

c) The proposed measure is connected with bathing and outdoor activity for the general public or is essentially of such a kind that it was must located near or in water, e.g. changing rooms and landing stags near bathing points, harbour facilities.

d) The measure caters to an urgent public interest.

e) The shore comes within an area designated in the municipal comprehensive plan as an area for rural development and the proposed building development (1) furthers rural development or (2) refers to a single or two-family dwelling adjoining an existing dwelling house.

The travaux préparatoires further emphasise that an exemption cannot be justified by the stretch of shore in question seldom being visited by the general public or the terrain and vegetation being of such a kind as to make it uninteresting for purposes of bathing and outdoor activity. Regional or local differences of access to undeveloped shores, like differences in the pressure of human settlement, may only be taken into account with regard to building measures capable of furthering rural development. Otherwise, e.g. in the case of single, remotely situated buildings, it is emphasised that the provisions are to be uniformly applied throughout the country and that exemption applications are to be viewed restrictively. 9

In this connection the travaux préparatoires raise the issue of principle concerning a reasonably balance or proportionality between a property owner's interest in using her property, e.g. for building, and on the other hand the public interest which shore protection represents. The proportionality requirement, the argument continues, is provided for ipso facto if the shoreline protection does not impose constraint on current lawful use of the land and permits new buildings or other measures necessary for farming and forestry, fishing or reindeer husbandry.10 With the exception, then, of these last mentioned measures, the intention is for building to be generally prohibited on all shores accessible by virtue of the Right of Public Access. No balances - between the benefit to the individual of building on

$7 \quad$ Landowners are not entitled to compensation for refusal of exemption or for shore protection orders affecting their properties.

8 Following a statutory amendment effective from 1st July 2009, SFS 2009:532, Chap. 7, Section 18c-d of the Environmental Code.

9 Prop. 2008/09:119 pp. 53 and 105.

10 In Prop. 2008/09:119 p. 53, reference is made to Prop. 1997/98:45, pp. $321-322$. 
an developed shore and the extent to which the shore is deserving of protection - are to be struck on the merits of individual cases. Building is only permissible if one of the above mentioned "special reasons" prevails, in which case balances have to be struck between shore protection and the interest of implementing the measure contemplated.11

\section{History}

Two private members' Bills in the 1936 Riksdag (parliament) called for measures to assure the "non-landowning urban population" of access to bathing and outdoor recreation areas within reasonable distance of their residential locality. ${ }^{12}$ This was prompted by the growth of secondary home development on the outskirts of towns and cities. The situation in the Stockholm archipelago was regarded as especially problematic.13 The upshot was the appointment of a Commission which proposed legislation on building in shoreline locations. ${ }^{14}$ That Commission's proposals, however, did not lead to the enactment of any legislation, and with the outbreak of war the debate lapsed.

The 1947 Building Act was made to include provisions conferring on the county administrative board certain limited powers of prohibiting building development in areas needing to be protected by reason of their natural beauty, their vegetation or other particular natural attributes. This was partly prompted by a realisation that access to shores was in the process of disappearing in some places, especially in the environs of urban communities ${ }^{15}$, but it was not until 1950 that special legislation was enacted for shore zones, in the form of a stopgap law prohibiting building development for the time being16, superseded not long afterwards by the 1952 Shorelines Act. ${ }^{17}$

The 1952 Act had an expressly social purpose, namely that of securing public access to shore zones. The county administrative board could order that no building development was to take place within a certain shoreline zone without its permission. In other words, a selective shore protection, in contrast to the general rules in force today. The Shorelines Act also included rules whereby landowners refused building permission would in certain cases be entitled to financial compensation. In the Commission report on which the Act was based 18 , it was pointed out that a balance had to be struck between the interest of the general public in recreation and the interest of private individuals in developing the land. The intention was for shoreline building development to be directed to places suitable for it from the viewpoint of the general public. 19

\footnotetext{
11 See Chap. 7, Section 25 of the Environmental Code.

12 Segrell 1995: 57.

13 Segrell 1995: 75.

14 SOU 1938:45 and SOU 1940:12.

15 Ds 2008:21 p. 41.

16 SFS 1950:639.

17 SFS 1952:382.

18 SOU 1951:40.

19 Biällerstedt et al. 1979: 13.
} 
The provisions of the 1952 Shorelines Act were subsequently incorporated in the 1964 Nature Conservancy Act. ${ }^{20}$ At the same time the rules were expanded so as also to include certain types of construction other than the erection of buildings. The right to compensation when refused building permission was abolished in 1972.21

In 1975 shore protection was expanded to include all shoreline zones22, just as it does today, and the provisions were amended at the same time so as to tighten up the implementation of the Act. The requirement of building permission was replaced with an express prohibition of building, and exemptions were now made conditional on special reasons. The driving forces here were the rapid growth of secondary homes development and a feeling that shoreline protection orders had not been made in sufficient number, at the same time as it was felt that far too many building permits had been granted within shoreprotected areas. 23

In 1994 the purpose of shore protection was enlarged so as also to include the protection of flora and fauna. At the same time it was resolved that the National Environmental Protection Agency was continue the work already begun on framing a differentiated shore protection ${ }^{24}$, the intention being to facilitate regional and local adaptation of the general rules, with allowance made for population density, the abundance or otherwise of lakes and watercourses and distances from major conurbations. 25 This remit, however, was revoked following the change of Government in 1994.

In 1999 the Nature Conservancy Act was incorporated in the new Environmental Code with its shore protection provisions virtually unaltered.

The shore protection provisions of the Environmental Code were amended with effect from 1st July 2009, partly in order to provide, in areas with a plentiful supply of undeveloped shores and low pressure of human settlement, certain possibilities of building conducive to rural development. These areas are to be indicated in the municipal comprehensive plans. This local adaptation of shore protection does not apply, however, for individual, remotely situated single and two-family dwellings. On the contrary, where buildings of this kind are concerned the amendment represents a tightening up of the rules, in that the grounds for exemption are defined in the statutory text, which limits them to the strict view which has evolved since 1975 through travaux préparatoires and case law.

20 SFS 1964:822.

21 Jonzon et al. 1988: 100.

22 SFS 1974:1025.

23 Prop 1974:166 p. 94.

24 Prop 1993/94:229.

25 lbid. p. 11. 


\section{Shore Access}

The total length of shoreline along coasts, round islands and lakes and alongside watercourses 26 in Sweden is approximately $385,000 \mathrm{~km} .{ }^{27}$ This is ten times the earth's circumference - an almost incredible figure, rendered more plausible and understandable by a closer look at the Swedish landscape. Geological conditions have given rise to a large number of lakes and watercourses, the shores of which total some $312,000 \mathrm{~km}$ in length. Most of the lakes are embedded in forest and mountain landscapes, which make up roughly 80 per cent of the country's area. ${ }^{28}$ Often the lakes are remote from any human settlement. The character of the landscape and the great abundance of lakes are best seen from maps, or else through the aircraft window! A few maps are given here (App. 1-3) to convey some idea of just how prominent a feature lakes are in the Swedish landscape.

To this are added the coasts. The coastline is in many places indented and broken by numerous inlet and islands, the Stockholm archipelago being a prime example in this respect. Coastal beaches in Sweden, islands included, total some 73,000 km.

What is most interesting, however, is the quantity of undeveloped beaches. ${ }^{29}$ Only then does it emerge that out of a total of 385,000 km of shoreline in Sweden, some 10 per cent is developed. 30 Conditions vary, however, from one region or community to another, depending among other things on geographic conditions. Besides - and quite naturally so - the proportion of developed shore is smaller in sparsely populated areas than in urban areas and their hinterlands. In the most northerly county - Norrbotten - there are $86,000 \mathrm{~km}$ of shores, of which 4 per cent are inhabited. In the County of Stockholm there are 14,000 $\mathrm{km}$ of shores and 26 per cent of these are built-up areas. Some more examples are given below, at municipal level, illustrating regional differences with regard to shore access. ${ }^{31}$

The shores within the Municipality/City of Stockholm total $208 \mathrm{~km}$ in length, of which 66 per cent is developed - not surprisingly for a city "built on the water". The archipelago extending eastwards from Stockholm has long been attractive for waterside building development, and at the same time much used for bathing and outdoor activity. The supply of undeveloped shores in these coastal areas can be illustrated with conditions in the Municipality of Värmdö, which has a total of 3,386 km of shoreline, 27 per cent of which is developed.

26 Rivers more than 6 metres across.

27 Statistics Sweden, SCB 2002a: 1. Shorelines were measured from cartographical material to a scale of $1: 10,000$ (1: 50,000 in the mountain region).

28 Statistics Sweden, SCB [2008]. www.scb.se/templates/pressinfo_254451.asp.

29 The statistics for this date from 2002, subsequent building development does little to alter the overall impression. The data come from Statistics Sweden, SCB $2002 \mathrm{~b}$.

30 The expression "developed shore" as used here denotes the existence of one or more buildings within 100 metres of the shoreline.

31 Further statistics demonstrating regional differences in the situation with regard to undeveloped shores are given in App. 4. 
Further south along the Baltic coast there are archipelago areas where undeveloped shores are more abundant, in particular the Municipality of Västervik with 3,650 km of shoreline, 10 per cent of it developed, and the Municipality of Oskarshamn, which has 2,368 $\mathrm{km}$ of shoreline, again 10 per cent of it developed.

Looking westwards at the coast north of Göteborg (Gothenburg), the total length of shoreline is less, but at the same time the developed proportion is smaller than in the Stockholm archipelago. The Municipality of Tjörn, for example, has $881 \mathrm{~km}$ of shoreline/14 per cent developed, and Orust has $975 \mathrm{~km} / 18$ per cent developed.

The coastal communities in the south, overlooking Öresund (the strait between Sweden and Denmark) have no archipelago and their landscape presents few lakes or watercourses, which means a limited supply of beaches. Thus Landskrona has $108 \mathrm{~km}$ of shoreline/35 per cent developed and Helsingborg $142 \mathrm{~km} / 32$ per cent developed.

A different situation prevails inland. There the landscape is predominantly forested and in most places includes a large number of lakes and watercourse, often in remote locations, In the north of Sweden, for instance, the Municipality of Arjeplog has 15,360 $\mathrm{km}$ of shoreline, 1 per cent of it developed. Vilhelmina has $6,212 \mathrm{~km}, 4$ per cent of it developed. Further south we find the inland municipality of Torsby, with 3,453 shoreline/ 8 per cent developed, and Älvdalen with $6,747 \mathrm{~km} / 3$ per cent developed. The forest communities furthest south can be instanced with the Municipality of Ljungby, with its 1,673 km of shoreline, 9 per cent of it developed.

Even if the supply of undeveloped shore is good in large parts of the country, especially by international standards, there are areas where the supply is limited. In addition to the above mentioned examples from Öresund, inland there are a number of farming areas with few lakes and no contact with the sea, e.g. the Municipality of Mjölby, with $190 \mathrm{~km}$ of shoreline/22 per cent developed, and the Municipality of Vara, with $223 \mathrm{~km} / 20$ per cent developed.

Summing up, undeveloped beaches are in good supply, but it should be emphasised that, even if a shore zone is accessible to the general public - by authority of the Right of Public Access - it can still be of little value for bathing and outdoor activity purposes. Perhaps it is unattractive due to "unpleasant" surroundings (noisy, close to industrial activity etc.). Or perhaps the terrain and vegetation make it difficult for people to visit and use the shore. If, moreover, the place is hard to reach, due to its being in a remote location or the terrain being impassable, then its value to the general public may be practically nil. Unfortunately, no nationwide qualitative studies of shores are available32, but it is readily apparent that many accessible shores are unsuitable for bathing, which can justify particular restraint with regard to building development in shore areas more amenable to bathing. At the same time, it ought to be possible for low-grade shores to be built on to a certain extent, about which more presently.

32 Minor studies do exist, however; cf. below under the heading "How was the prohibition of building along all shores justified?" 


\section{Riparian Building Development in Sparsely Populated Areas}

The point on which I take issue with shore protection concerns its strict application in sparsely populated areas with a good supply of beaches and a low level of building activity. ${ }^{33}$ The small volume of building in large parts of Sweden is apparent from the following table, which contains examples at county level, from north to south. The figures refer to the number of buildings added between 1996 and 200034, expressed here as annual averages. Some 90 per cent of the buildings were secondary or year-round homes. Despite being a few years old, these data convey some idea of the extent of building development in relation to the amount of shoreline available.

\begin{tabular}{|l|c|c|c|}
\hline County & Shore, $\mathrm{km}$ & $\begin{array}{l}\text { New buildings } \\
\text { within } 100 \mathrm{~m} \text { of } \\
\text { shore/yr }\end{array}$ & $\begin{array}{l}\text { New buildings } \\
\text { more than 100 m } \\
\text { from shore/yr }\end{array}$ \\
\hline Norrbotten & 85,659 & 83 & 120 \\
\hline Västerbotten & 48,981 & 64 & 158 \\
\hline Jämtland & 45,085 & 21 & 101 \\
\hline Västernorrland & 17,659 & 42 & 62 \\
\hline Värmland & 18,876 & 44 & 97 \\
\hline Kalmar & 12,560 & 29 & 136 \\
\hline Kronoberg & 7,573 & 19 & 122 \\
\hline
\end{tabular}

The available statistics do not show differences existing in every county, between different municipalities. In several of the really sparsely populated inland municipalities, practically nothing is being built close to water. Here are two eloquent instances from 2008. The Municipality of Arjeplog in Norrbotten: 4 new buildings in shore protection zones. ${ }^{35}$ The Municipality of Ljungby in the County of Kronoberg: 5 new buildings in shore protection zones. ${ }^{36}$ Furthermore, these buildings were in most cases located on previously developed land.

The statistics from the various counties do not show how large a proportion of waterfront or waterside building has taken place on, respectively, greenfield and brown-field sites, but building within 100 metres of the shoreline has probably to a great extent taken place on previously developed land. In some cases exemptions have probably been granted for

33 The 2009 statutory amendments have changed this situation to some extent, but there is still cause for criticism; see below.

34 Statistics Sweden, SCB. (2002). Housing changes along coast and shores. MI 50 SM 0301 and Statistics Sweden, SCB 2002a.

35 Personal Communication: Martin Stenlund, The Municipality of Arjeplog.

36 Personal Communication: Uno Samuelsson, The Municipality of Liungby. 
undeveloped land as being of little value for bathing and outdoor recreation - a rationale not normally acceptable according to the travaux préparatoires (see above).

If shore protection is relaxed in such a way the exemptions can be justified by a good supply of shores, the unpleasant terrain and vegetation of the place and so on, it is a reasonable supposition that the proportion of building development within 100 metres would increase. But, bearing in mind the smallness of the total volume of building in sparsely populated rural communities, building development in shore zones would remain so limited as to hardly pose any threat to the shores of such regions. True, building might increase in some quarters if attractive waterside or waterfront plots could be offered, but hardly on such a scale as to pre-empt any larger proportion of the shores.

\section{How Was the Prohibition of Building Along all Shores Justified?}

Many shores in Sweden have long been sought after for building development and at the same time of great value to the general public for bathing and outdoor activity. The clearest examples of this kind are to be found on the outskirts of central urban localities or in tourist areas where the natural environment and landscape are endowed with outstanding qualities. Elsewhere the pressure of human settlement is low, the supply of undeveloped shores is good and outdoor activity is limited. In addition, of course, there are in many places shore zones which are not at all attractive for bathing and outdoor activity. Despite these regional and local differences, in 1975 a general shore protection was introduced of the kind in force today, namely a prohibition of building development along all shores. What lay behind this decision?

Just as in the 1930s, it was fears of a secondary home development sprawl along the banks and beaches. ${ }^{37}$ In 1957 there were roughly 180,000 secondary homes in Sweden. By 1970 this had risen to nearly half a million. 38 One-third of the secondary homes built between 1960 and 1969 were sited on banks and beaches. ${ }^{39}$ In some circles there was growing concern over excessive shoreline building development.

In 1969 the National Board of Physical Planning and Building carried out a field reconnaissance of the mainland coast 40 including islands with bridge connections, the purpose being to clarify the supply of shores suitable for bathing and outdoor activity. The reconnaissance report showed 21 per cent of the coast to be entirely blocked by building development and 19 per cent partly blocked. Further studies of the County of Stockholm and the Göteborg region were added to the survey in 1970. In them a note was made of banks and beaches unsuitable for bathing (stony, steep etc.) or occupied by building develop-

\footnotetext{
37 Segrell 1995: 93.

38 Lindgren 1989: 20.

39 Larsson and Rönström 1979: 64.

40 Statens planverk 1971. The survey did not include Norrbotten or Gotland.
} 
ment. This revealed among other things that 16 per cent of the Stockholm County coastline (including islands with bridges to the mainland) could be used for bathing.41

The findings from the above mentioned coastal inventories, together with the expansion of secondary homes development, fuelled demands at the beginning of the 1970s for more effective shore protection. Following recommendations by the so-called Nature Conservancy Committee $(\mathrm{NVK})^{42}$, proposals were put forward for a stricter shore protection to apply everywhere in the country. The focus of attention was on the situation along the coasts and round about the major urban communities. Neither Government Commissions nor the Government itself appear to have paid much attention to the situation inland or in the sparsely populated regions of Sweden.

\section{Critique and Statutory Amendment}

The proposed general shore protection already came in for criticism at the time of its first presentation. The Norrbotten County Administrative Board, for example, saw no need for general rules for 47,000 lakes and all the water courses in a county which was to a great extent sparsely populated and where there was little pressure on banks and beaches. 43

General shore protection has remained a topic of debate ever since its introduction in 1975. Media coverage has often been to the tune of "shore protection in danger, more and more exemptions being granted". ${ }^{44}$ There has been less media coverage of the criticism coming from those who find shore protection an excessively rigorous piece of legislation. But, although less publicised, the opinion has been voiced in several quarters that shore protection should be adapted to regional and local conditions and that more exemptions should be possible in sparsely populated areas. It is above all county administrative boards and municipalities in the north of Sweden that have pleaded for this kind of differentiated shore protection. 45 In recent years more and more municipalities in sparsely populated areas - from north to south - have called for a shore protection adapted to local conditions. 46

As has already been mentioned under the heading "History", thoughts of adapting shore protection more closely to local conditions already existed in 1994.47 This process was curtailed following the change of government. Work on reforming the 1975 shore protection was resumed following a further change of government. In 2001 the Government commissioned the Swedish Environmental Protection Board to investigate the feasibility and consequences of both intensifications and relaxations of shore protection. The Gov-

\footnotetext{
41 Lindgren 1983: 71.

42 Jordbruksdepartementet 1974.

43 Segrell 1995: 98.

44 Segrell 1995: 176.

45 Segrell 1995: 174.

46 Fully 100 small rural municipalities are working together in the "SmåKom" organisation and in 2005 and 2008 jointly petitioned the Government for a differentiated shore protection.

47 Prop 1993/94:229.
} 
ernment subsequently presented several proposals for differentiated shore protection. The latest official report, in 200848, led to the Government Bill49 which has now been enacted, with effect from 1st July 2009. The basic principle is that shore protection will continue to apply to all shorelines, at the same time as more scope is to be allowed for cancelling or waiving it in certain places.

The latest amendment provides among other things for shore protection to be linked to the overarching physical planning incumbent on the municipalities under the Planning and Building Act.50 Municipalities will be able in their comprehensive plans to designate areas where shore protection can in certain cases be cancelled or waived, on the grounds that the proposed settlement contributes towards rural development. The circumstance of inhospitable terrain and vegetation making a place of negligible value for outdoor activity, despite its being accessible by virtue of the Right of Public Access, is not accepted as a cause for permitting building development, even if the place is located in a region with plenty of banks and beaches and low pressure of settlement. ${ }^{51}$ Thus far, then, the new provisions maintain the strict principles applied previously.

\section{Concluding Remarks}

In sparsely populated parts of the country, contribution towards rural development can now be taken into account in the examination of proposed riparian building development. This provision should be viewed in the context of a desire on the part of the rural municipalities for building development as a means of counteracting population loss and retaining public services. The possibilities of achieving this will be augmented if the municipality can allow attractive riparian building development. In my opinion it is reasonable that such a balance should be permitted between the value of building and the value of undeveloped shores.

Even if a certain building project does not further the development of the municipality or the locality, obviously it still has an intrinsic value - at least, to the builder. Here again, the value of the proposed measure should be balanced against shore protection. It should further be emphasised that the value of keeping a place undeveloped - for the sake of bathing, outdoor activity, flora and fauna - can hardly be of the same magnitude everywhere in the country. A shore protection which, for every proposed building development, includes a balancing of interests and takes conditions on the spot as its starting point ought, in theory at least, to lead to more efficient land use. One argument against more "flexible" rules of this kind, opening the way to more exemptions in sparsely populated areas, could be that implementation will be difficult and developments hard to monitor. But, given the good supply of banks and beaches and the low level of building activity (cf. above), it is hard to see how shores in sparsely populated areas could be built up to

\footnotetext{
48 Ds 2005:23 and Ds 2008:21.

49 Prop. 2008/09:119.

50 SFS 1987:10.

51 Prop. 2008/09:119, pp. 104-105. See also Ds 2008:21 pp. 74-76.
} 
such an extent as to jeopardise the bathing and outdoor activity of the general public. For the same reason, it is hard to see how a differentiated shore protection would jeopardize the flora and fauna of sparsely populated rural areas.

Not infrequently, the fact of the Swedish rules of shore protection still not being based on the principle of balancing interests in individual cases leads to official decisions which are inexplicable to the individual. Clear examples of this kind occur when people in the most sparsely populated districts apply for exemption from shore protection, e.g. in order to build a weekend cottage or a simple hunting lodge. Even if the place is in an isolated location and the terrain and vegetation of the shore make the place uninteresting to the general public for purposes of bathing and outdoor activity, the answer is still No - in keeping with the principles laid down in the travaux préparatoires of the existing legislation. The 2009 amendment has not changed this. On the contrary, that amendment stresses that individual, remotely situated buildings are not to be permitted, because " ... in certain cases there would not be any large unspoiled shore protection zones left in the long run." 52 A strict principle of this kind may be reasonable in certain parts of Sweden, but hardly for the country as a whole, considering the differences in building development activity and riparian access. General provisions of this kind impair the credibility of the legislation.

Another question worth asking is whether a differentiated shore protection should be based on comprehensive physical planning. In the above mentioned statutory amendment, the idea is for the municipality in its comprehensive planning to designate places where shoreline building development will be permitted, on the grounds of benefiting rural development. There are many rural municipalities where only a few building cases are processed every year. The question is what amount of resources should be devoted to comprehensive planning of forest and rural areas, as a preliminary to the examination of just a few shoreline protection cases. As I see it, moreover, the examination of an individual exemption application ought to a great extent to be based on conditions on the spot - a level of detail beyond the grasp of comprehensive land use plans.

So, finally, what is the solution of the incoherent balance between the individual interest and shore protection provisions? In my view the Environmental Code should be amended so that exemptions from the general provisions can be justified by the stretch of shore in question seldom being visited by the general public or the terrain and vegetation being of such a kind as to make it uninteresting for purposes of bathing and outdoor activity.

\section{References}

Bjällerstedt V.-D., Norberg M. and Zinders R. [1979]: Något om skyddet för det rörliga fruluftslivet - särskilt strandskydd. Uppsala University, Faculty of Law.

Ds 2005:23: Ett förnyat strandskydd. Departementsserien (Ds) 2005:23. Government Officies of Sweden, Ministry of the Environment.

52 Prop. 2008/09:119 p. 71. 
Ds 2008:21: Stranden - en värdefull miljö. Departementsserien (Ds) 2008:21. Government Officies of Sweden, Ministry of the Environment.

Jonzon S.-G., Delin L. and Bengtsson B. [1988]: Naturvårdslagen. En kommentar. Stockholm, Norstedts.

Jordbruksdepartementet [1974]: Naturvård I - Strandskydd Landskapsvård Förvaltning. Ds Jo 1974:1. Stockholm, Jordbruksdepartementet.

Larsson G. and Rönström M. [1979]: Fritidsboende och fritidsbebyggelse. R23:1979.

Stockholm, Statens råd för byggnadsforskning.

Lindgren E. [1983]: Strandskyddsbestämmelsernas tillämpning och funktion. Meddelande 4:37, TRITA-FAT 37. Stockholm, Tekniska högskolan i Stocjholm (KTH), Institutionen för fastighetsteknik.

Lindgren E. [1989]: Fritidsbebyggelsens produktionsförutsättningar. R51:1989. Stockholm, Statens råd för byggnadsforskning.

Prop 1974:166: Kungl. Maj:ts proposition med förslag till ändringar i naturvårdslagen (1964:822) och skogsvårdslagen (1948:237), m.m. Stockholm, The Swedish Parliament.

Prop 1993/94:229: Strandskydd. Regeringens proposition. Stockholm, The Swedish Parliament.

Prop. 1997/98:45 Miljöbalk. Del 2. Regeringens proposition. Stockholm, The Swedish Parliament.

Prop. 2008/09:119 Strandskyddet och utvecklingen av landsbygden. Regeringens proposition. Stockholm, The Swedish Parliament.

Segrell B. [1995]: Den attraktiva kusten. Water and Environmental Studies, Linköping University. pp. 57, 93. 98, 174, 176.

SOU 1938:45 Betänkande med förslag angående reglering av strandbebyggelsen m.m. Stockholm, Socialdepartementet.

SOU 1940:12 Betänkande med utredning och förslag angående inrättande av fritidsreservat för städernas och de tätbebyggda samhällenas befolkning. Stockholm, Socialdepartementet.

SOU 1951:40 Förslag till lagstiftning om förbud mot bebyggelse m.m inom vissa strandområden. Stockholm, Justitiedepartementet.

SFS 1950:639 Lag om tillfälligt byggnadsförbud inom vissa strandområden.

SFS 1952:382 Strandlagen.

SFS 1964:822 Naturvårdslagen.

SFS 1974:152 Regeringsformen, Chap. 2, Section 18 (3).

SFS 1974:1025 Lag om ändring i naturvårdslagen.

SFS 1987:10. The Planning and Building Act.

SFS 1998.808. The Environmental Code. 
SFS 2009:532. The Environmental Code Chap. 7, Section 18c-d.

Statens planverk [1971]: Kustinventeringen 1971. Rapport 14. Stockholm.

Statistics Sweden, SCB [2002a]: Coast and shores in Sweden. MI 50 SM 0201. Stockholm.

Statistics Sweden, SCB [2002b]: Coast and shores influenced by buildings. MI 50 SM 0202.

\section{Appendix 1}

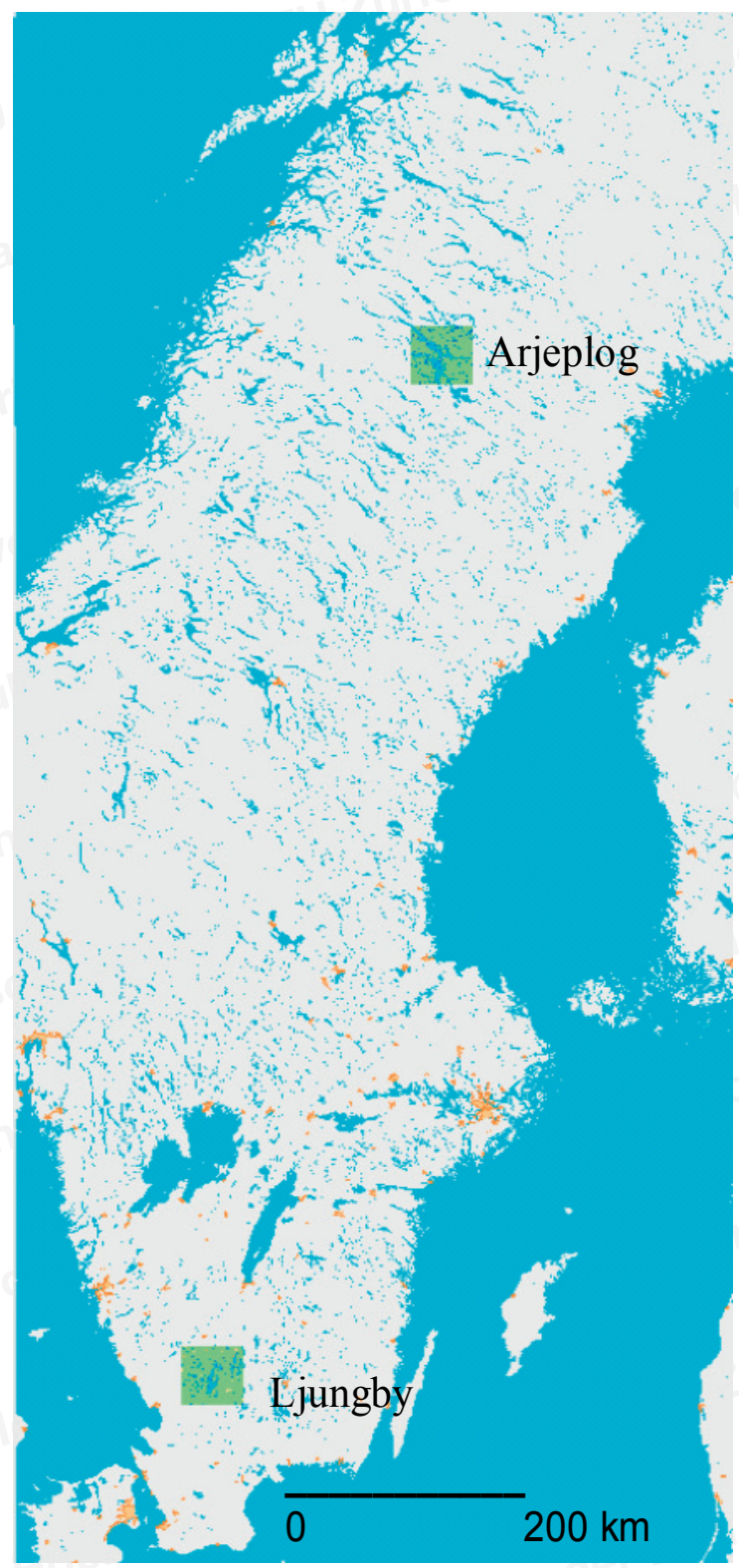

Lantmäteriet Gävle 2008 .

Medgivande I 2008/2026 


\section{Appendix 2}

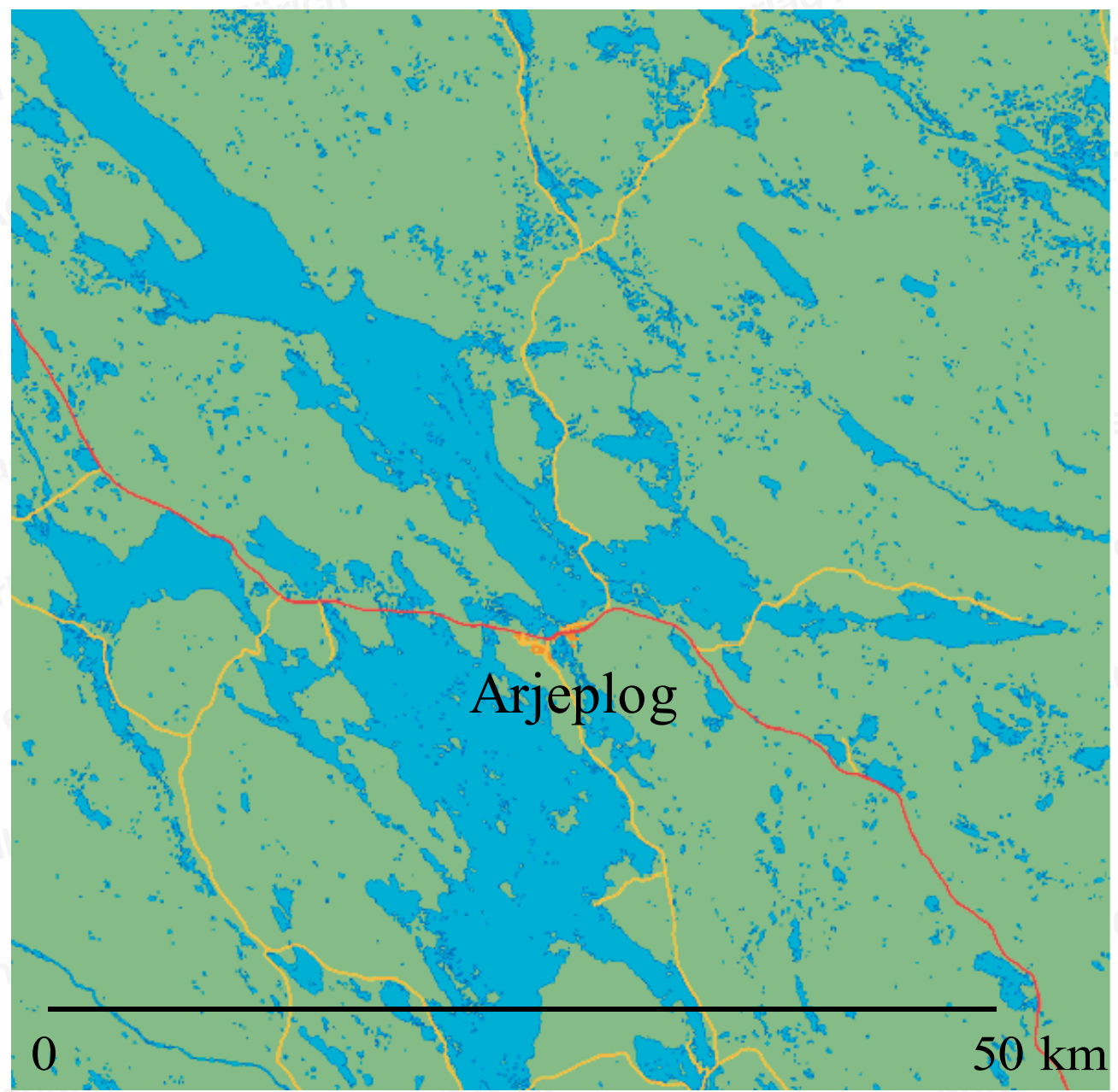

Lantmäteriet Gävle 2008. Medgivande I 2008/2026 
Appendix 3

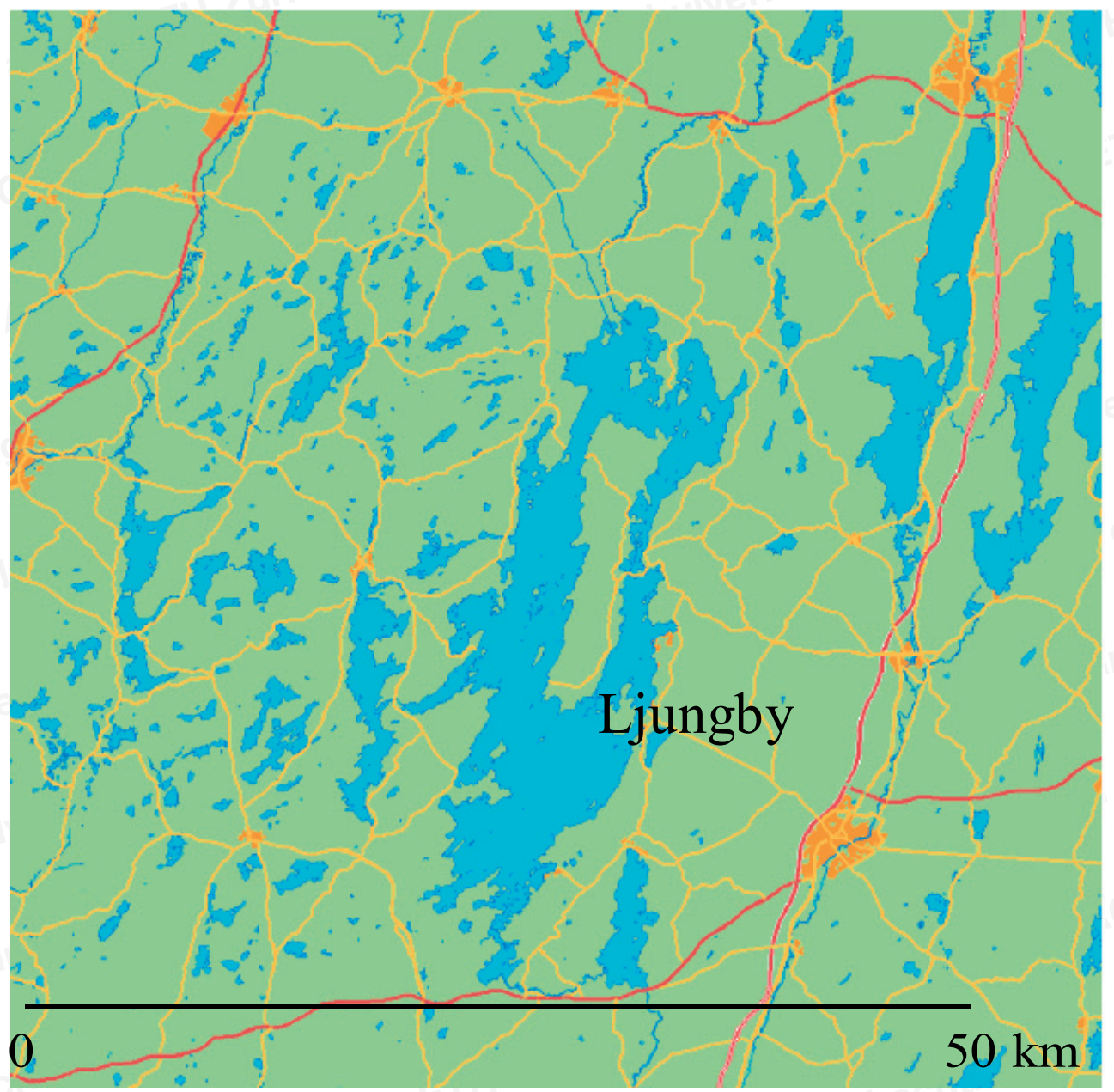

Lantmäteriet Gävle 2008 . Medgivande I 2008/2026 


\section{Appendix 4}

Statistics Sweden, SCB (2002). Coast and shores influenced by buildings. MI 50 SM 0202. Coast and shores influenced by buildings (building within $100 \mathrm{~m}$ ), by municipality

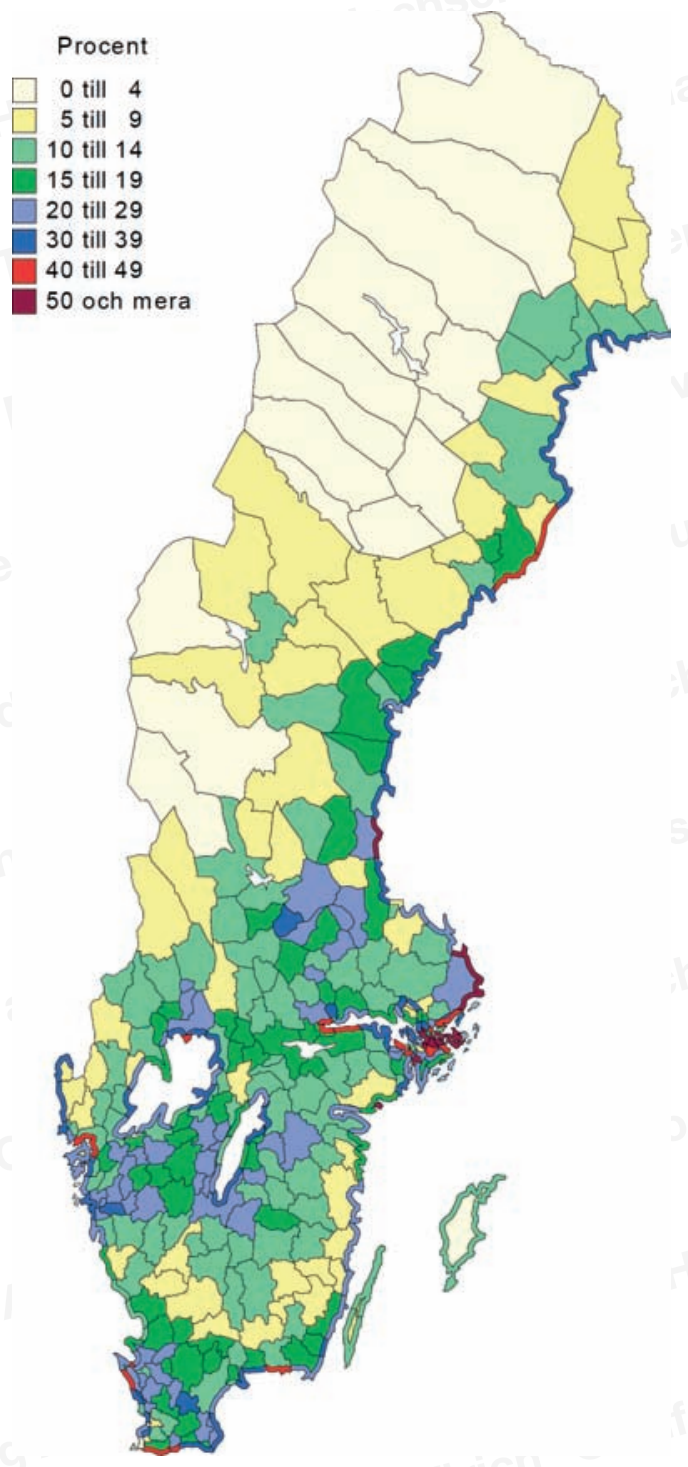

